\title{
Supplementary files for
}

\section{GRACE Water Storage Estimates for the Middle East and Other Regions with Significant Reservoir and Lake Storage}

\section{Submitted to HESS}

In discussion in HESSD

35 (1) CNRS - Géosciences Rennes UMR 6118, Université de Rennes 1, Rennes, France

(2) Department of Geological Sciences, Jackson School of Geosciences, The University of Texas at Austin, Austin, TX, USA

(3) Bureau of Economic Geology, Jackson School of Geosciences, The University of Texas at Austin, Austin, TX, USA

(4) CNES/LEGOS, 14, av. Édouard-Belin, 31400 Toulouse, France

1. Numerical Experiment 1

2. Numerical Experiment 2

3. SH spectra for example regions Erreur ! Signet non défini.

4. Tigris-Euphrates Basin - LSM Estimates ......

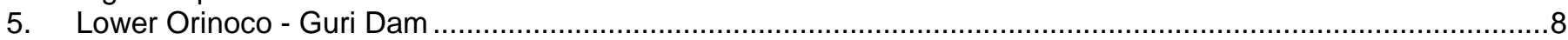

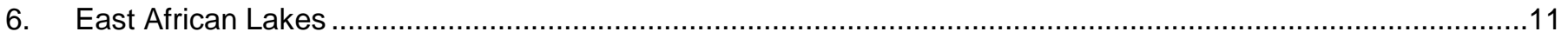




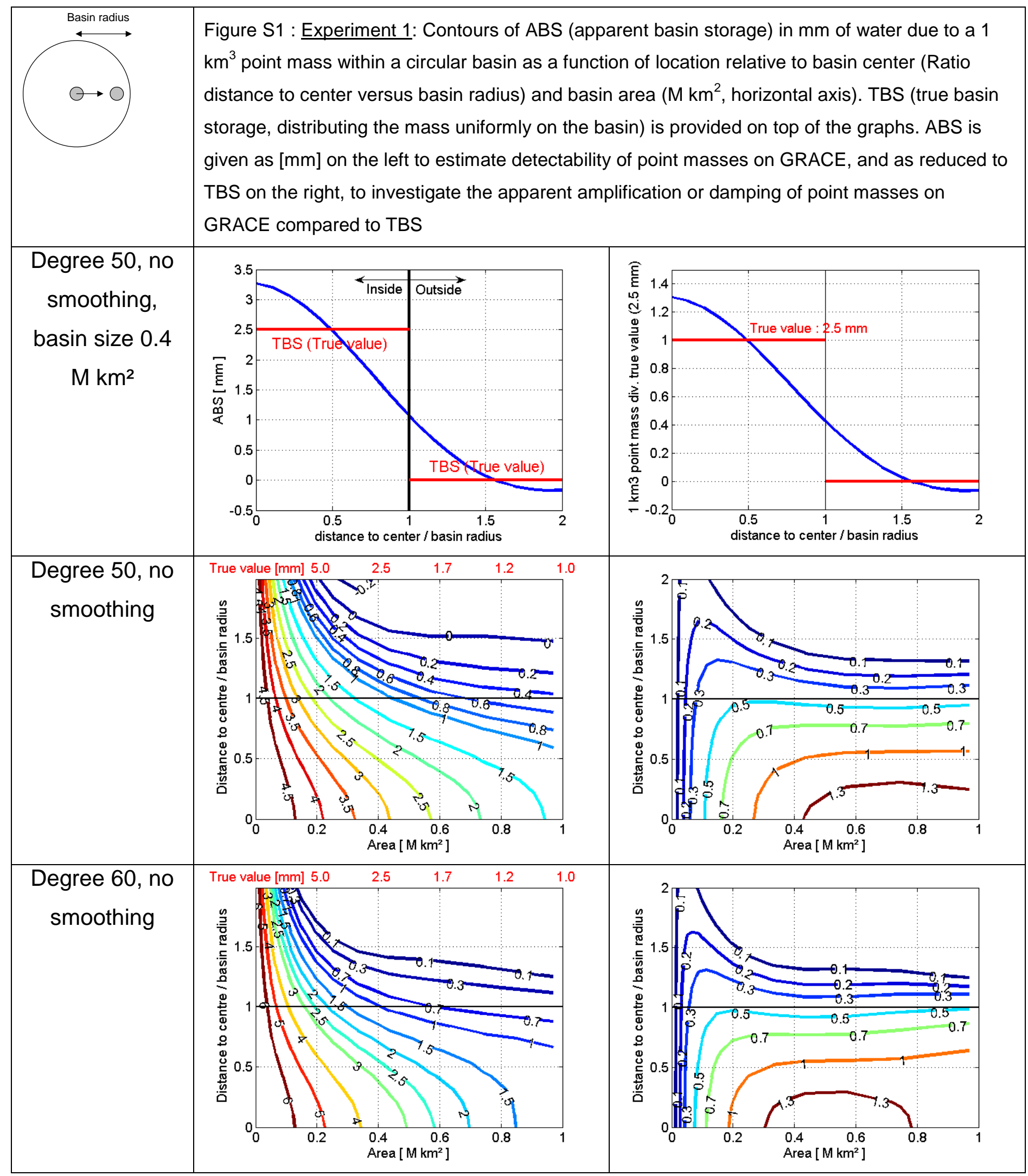




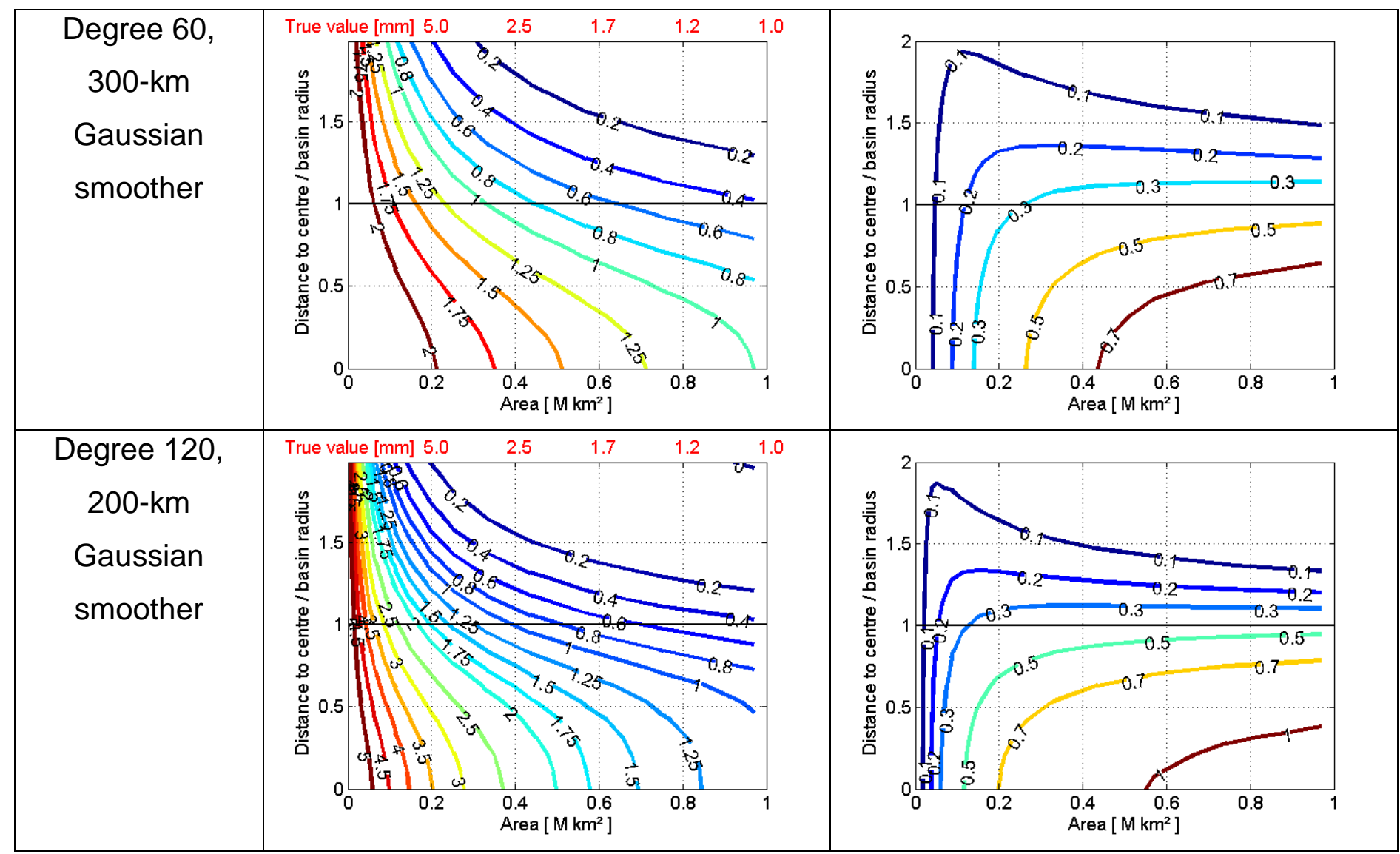




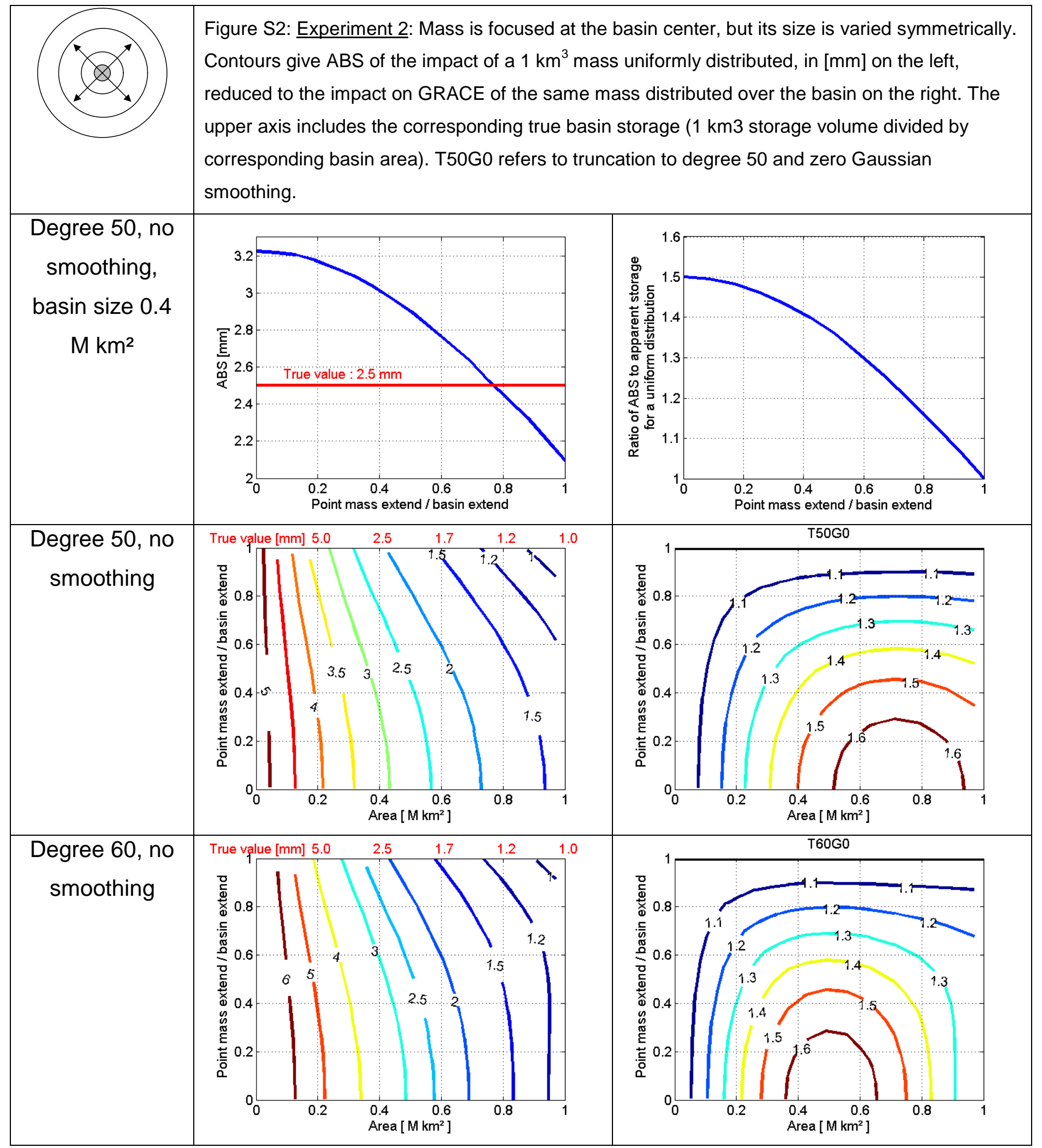




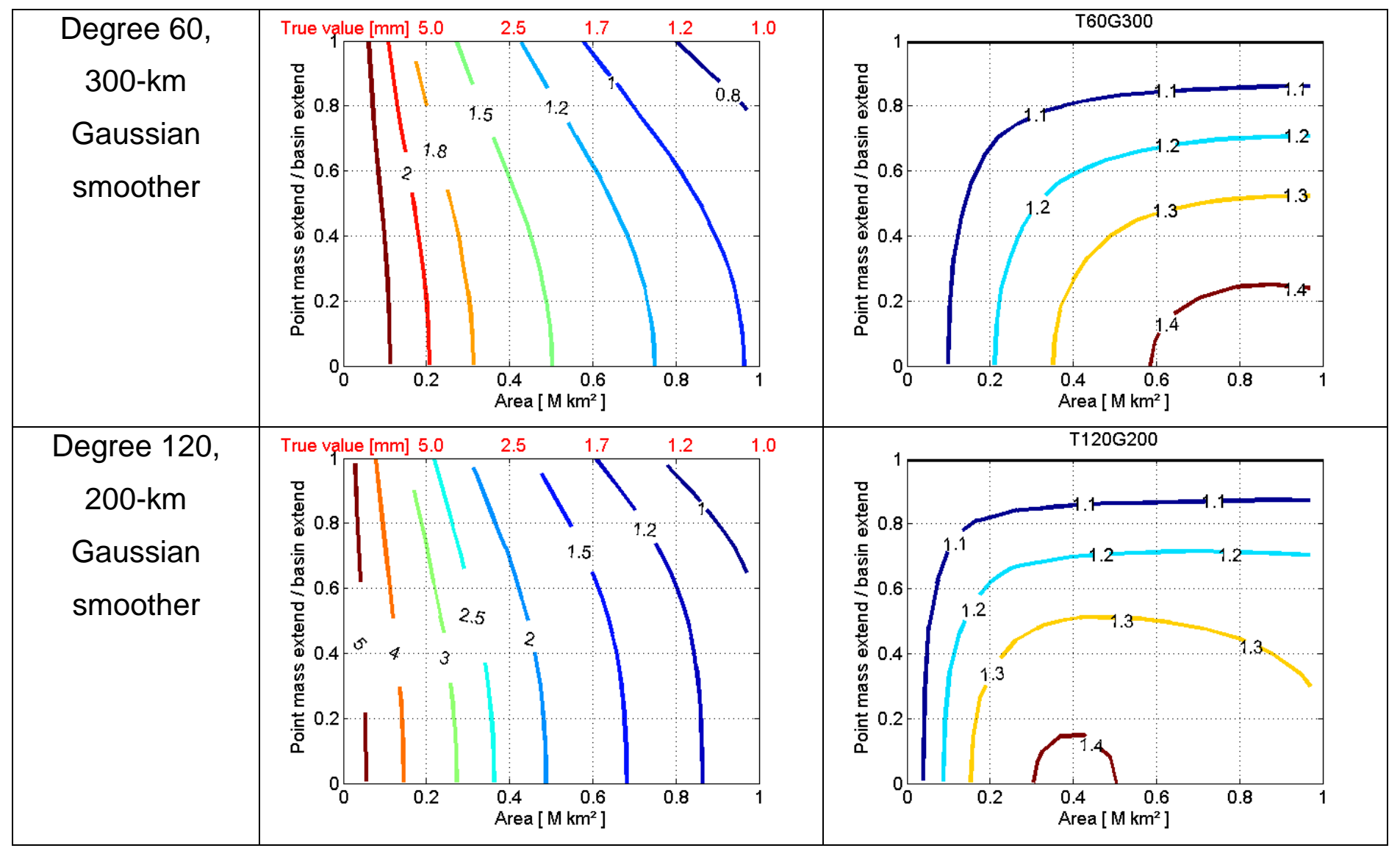

5. 
3. Table S1: Lake and Reservoir Data Summary.

\begin{tabular}{|c|c|c|c|c|}
\hline Region & Lake name & Area $\left[\mathrm{km}^{2}\right]$ & $\begin{array}{c}\text { Variability } \\
{\left[\mathrm{km}^{3}\right]}\end{array}$ & $\begin{array}{c}\text { Volume I } \\
\text { Level data }\end{array}$ \\
\hline Lower Nile (410 000 km²) $^{2}$ & Aswan & $6200 \mathrm{~km}^{2}$ & $16 \mathrm{~km}^{3}$ & Level \\
\hline Lower Orinoco (350 000 km²) $^{2}$ & Guri & $3919 \mathrm{~km}^{2}$ & $23 \mathrm{~km}^{3}$ & \\
\hline \multirow[t]{10}{*}{ Tigris-Euphrates $\left(790000\right.$ km$\left.^{2}\right)$} & TOTAL & 15300 km $^{2}$ & $24 \mathrm{~km}^{3}$ & \\
\hline & Asad & 447 & 0.30 & Level \\
\hline & Ataturk & 707 & 1.6 & Level \\
\hline & Daryace & 5200 & 3.7 & Volume \\
\hline & Mossoul & 285 & 1.8 & Level \\
\hline & Qadisiyah & 415 & 3.3 & Volume \\
\hline & Razazah & 1501 & 1.9 & Level \\
\hline & Saksak & 458 & 1.7 & Volume \\
\hline & Tharthar & 2500 & 8.3 & Level \\
\hline & Van & 3755 & 1.0 & Level \\
\hline \multirow[t]{14}{*}{ East Africa (1 125000 km²) } & TOTAL & $175144 \mathrm{~km}^{2}$ & $86 \mathrm{~km}^{3}$ & \\
\hline & Albert & 5270 & 2.9 & Level \\
\hline & Bangwelu & 9840 & 3.9 & Level \\
\hline & Cahora Bassa & 2739 & 5.6 & Level \\
\hline & Edouard & 2150 & 0.48 & Volume \\
\hline & Kariba & 5400 & 10.6 & Level \\
\hline & Kivu & 2700 & 0.63 & Level \\
\hline & Kyoga & 1720 & 1.2 & Level \\
\hline & Malawi & 29500 & 14 & Level \\
\hline & Mweru & 5120 & 3.0 & Level \\
\hline & Rukwa & 2600 & 2.3 & Level \\
\hline & Tanganyka & 32900 & 12 & Level \\
\hline & Turkana & 6405 & 4.6 & Level \\
\hline & Victoria & 68800 & 25 & \\
\hline
\end{tabular}




\section{Tigris-Euphrates Basin - Land Surface Model (LSM) Estimates}

Table S2: Comparison between GRACE TWS, $\triangle$ SMS $+\Delta$ SWES from CLM, NOAH, MOSAIC, and VIC LSMS and $\triangle R E S S$ for Tigris-Euphrates basin. In all cases, adding predicted $\triangle R E S S$ contribution to LSM output results in better agreement with GRACE data

\begin{tabular}{|c|c|c|c|c|c|c|c|c|c|c|c|}
\hline & $\begin{array}{c}\text { GRACE } \\
\text { CSR }\end{array}$ & CLM & $\begin{array}{c}\text { CLM + } \\
\Delta \text { RESS }\end{array}$ & MOSAIC & $\begin{array}{c}\text { MOSAIC } \\
+ \\
\triangle \text { RESS }\end{array}$ & $\mathrm{NOAH}$ & $\begin{array}{c}\text { NOAH } \\
+ \\
\text { ARESS }\end{array}$ & VIC & $\begin{array}{c}\mathrm{VIC}+ \\
\Delta \mathrm{RESS}\end{array}$ & WGHM & $\begin{array}{c}\text { WGHM } \\
+ \\
\Delta \text { RESS }\end{array}$ \\
\hline $\begin{array}{c}\text { Amplitude } \\
\text { of seasonal } \\
\text { variations } \\
\text { [ } \mathrm{mm}]\end{array}$ & 63.1 & 22.7 & 23.4 & 56.6 & 62.9 & 44.2 & 45.2 & 47.7 & 49.1 & 39.7 & 40.8 \\
\hline $\begin{array}{c}\text { Phase } \\
\text { (seasonal) } \\
\text { [ days ] }\end{array}$ & Ref. & -36 & -15 & -16 & -1.2 & -29 & -17 & -26 & -16 & -29 & -16 \\
\hline Correlation & Ref. & 0.80 & 0.89 & 0.93 & 0.95 & 0.88 & 0.93 & 0.82 & 0.93 & 0.86 & 0.92 \\
\hline $\begin{array}{c}\text { RMS with } \\
\text { GRACE } \\
{[\mathrm{mm}]}\end{array}$ & Ref. & 47 & 38 & 25 & 20 & 34 & 25 & 37 & 27 & 36 & 28 \\
\hline $\begin{array}{c}\text { Trend } \\
(2002 / 10- \\
2009 / 09) \\
{[\mathrm{mm} / \mathrm{yr}]}\end{array}$ & -11 & -3.2 & -7.3 & -8.4 & -12 & -6.0 & -11 & -3.2 & -7.3 & -5.2 & -9.2 \\
\hline $\begin{array}{c}\text { Trend } \\
(2006 / 10- \\
2009 / 09) \\
{[\mathrm{mm} / \mathrm{yr} \text { ] }}\end{array}$ & -39 & -7 & -26 & -21 & -39 & -18 & -37 & -7.9 & -27 & -14 & -33 \\
\hline
\end{tabular}




\section{Lower Orinoco - Guri Dam}

a)

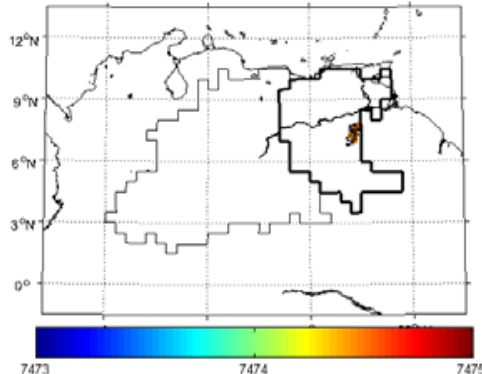

d) Orinoco basin $\left(1 \mathrm{M} \mathrm{km}^{2}\right)$

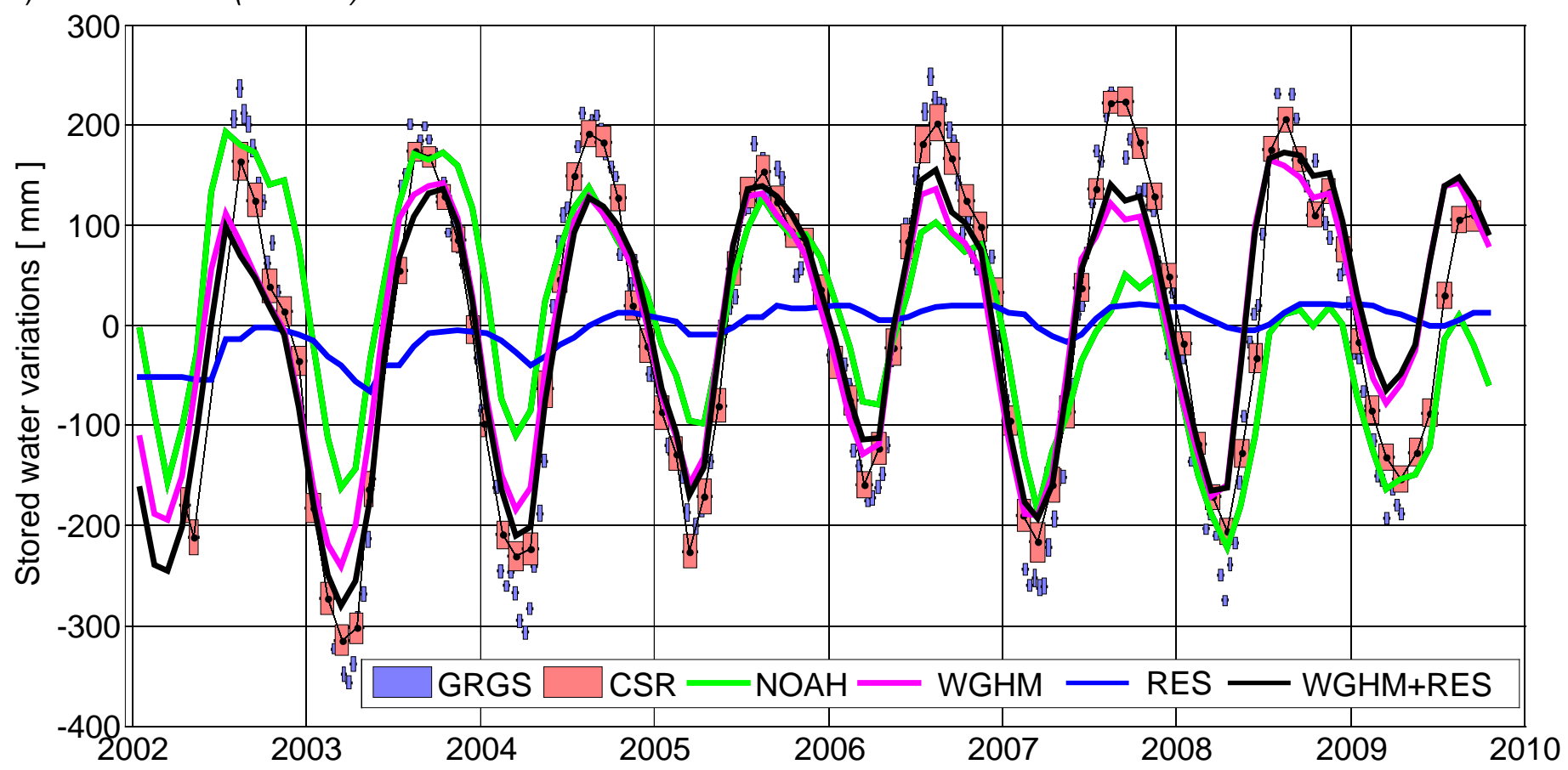

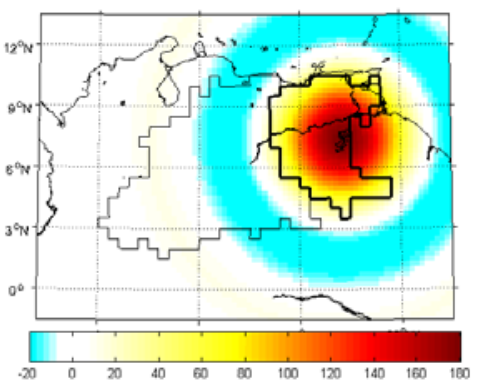

b)

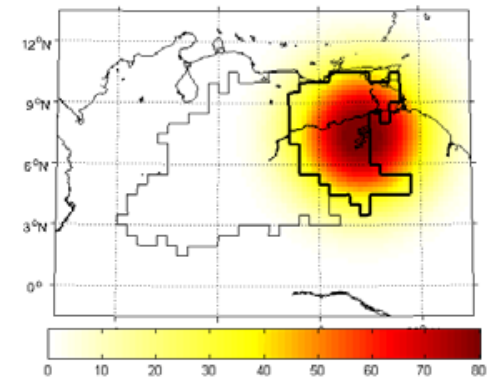

c)

e) Lower Orinoco basin $\left(350000 \mathrm{~km}^{2}\right)$

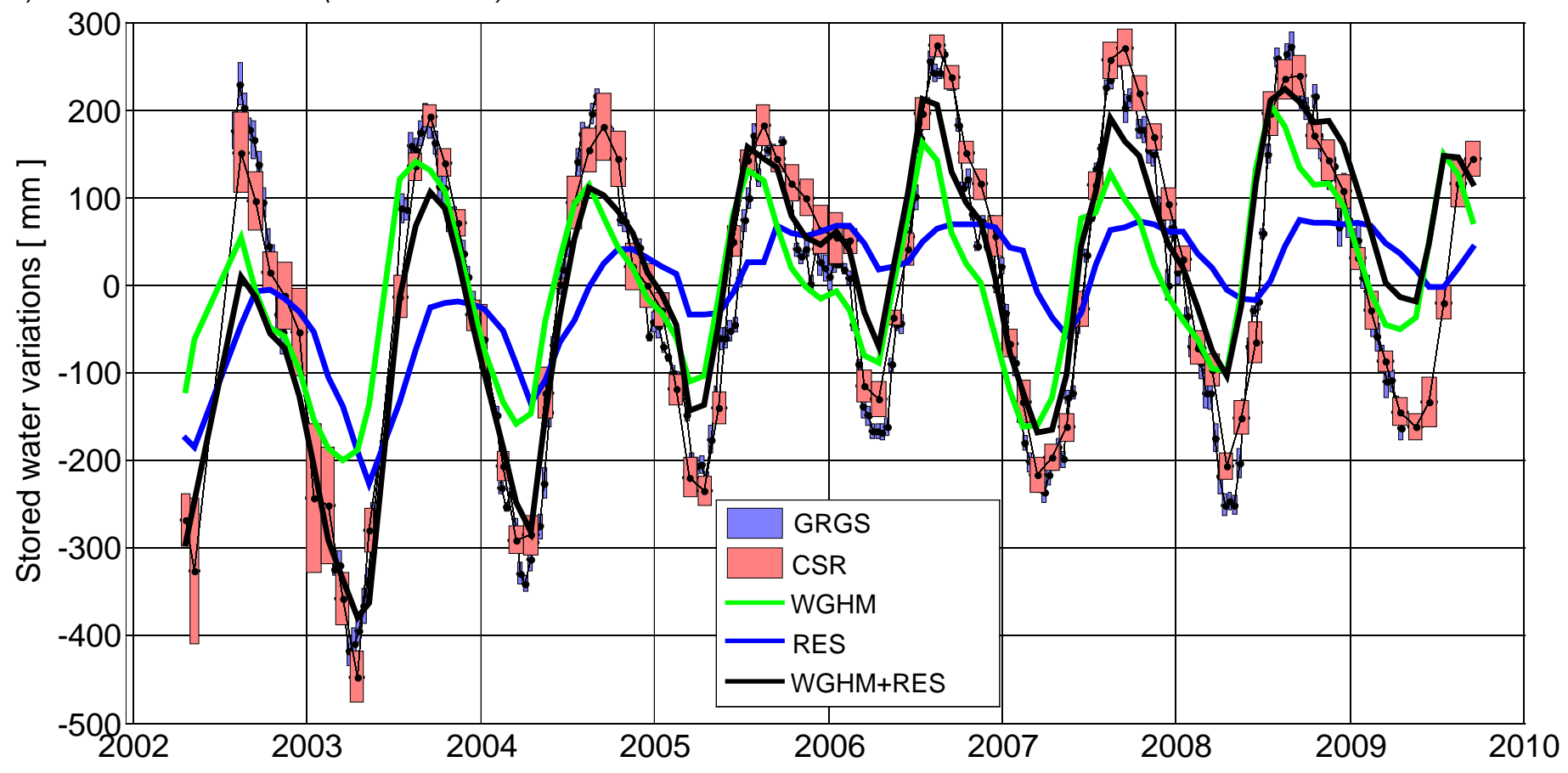




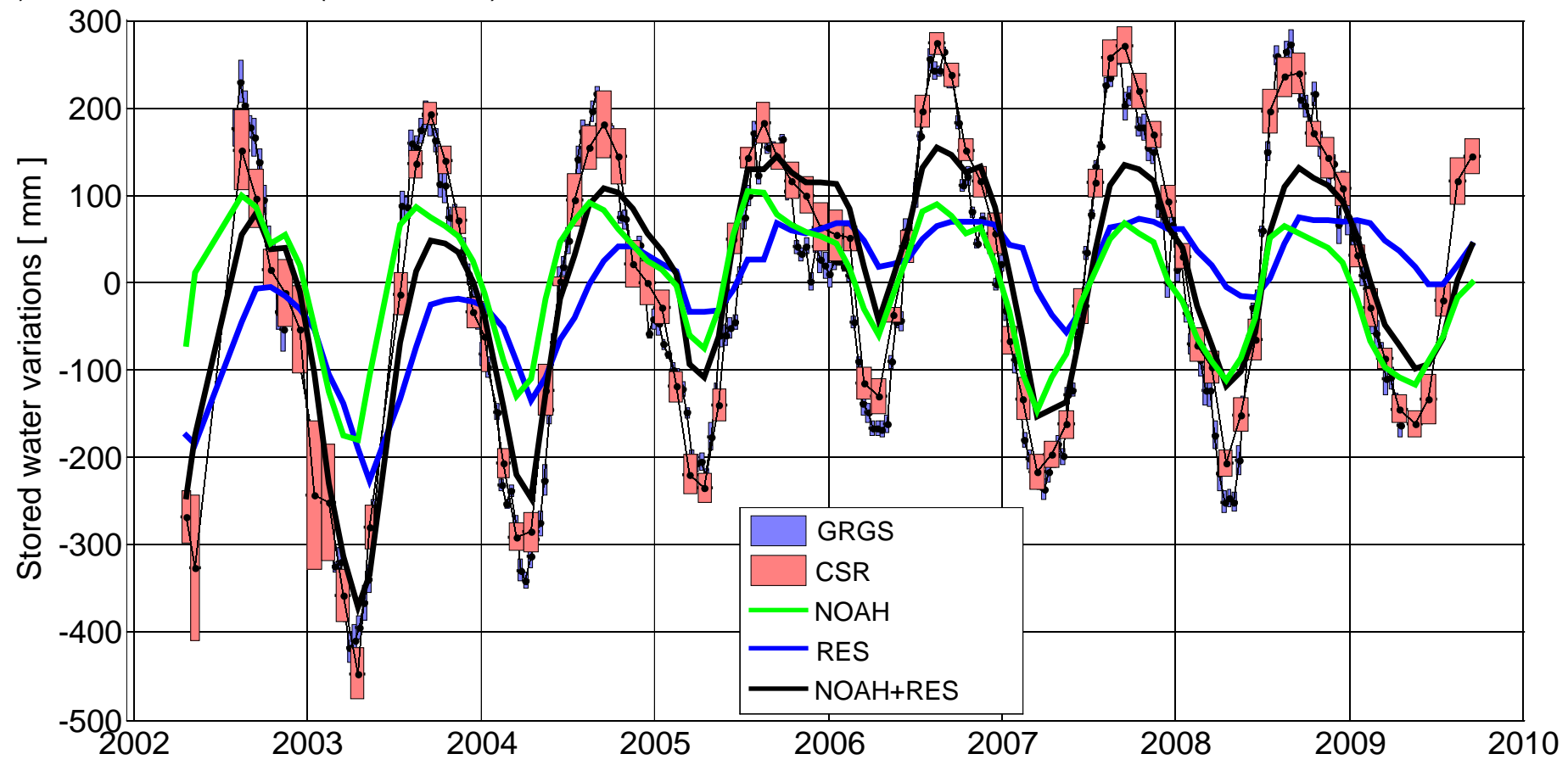

Figure S4: Lower Orinoco and Guri lake contribution. The Guri dam impounds the Caroni River (Venezuela) and creates a lake of $3919 \mathrm{~km}^{2}$. The first stage of the facility was completed in 1969 and completed in 1986, as a 162-m high earth and rockfill dam with a crest length of $11 \mathrm{~km}$. It is mainly used for hydropower purposes (capacity of $10300 \mathrm{MW}$ ) and supplies $\sim 50 \%$ of Venezuela's electricity. In contrast to Lake Nasser, Guri lake is located in a tropical climate with large natural storage fluctuations.

(a) Reservoir and standard deviation of Guri lake level variation within the basin,

(b) same map after truncation at degree 50 similar to GRGS processing,

(c) same map after truncation at degree 60 and 300-km Gaussian smoother applied, similar to CSR processing. The thick

line represents the lower Orinoco basin, the thin line shows the Oricono basin;

(d) GRACE Water storage variations in the Orinoco basin $\left(1 \mathrm{M} \mathrm{km}^{2}\right)$ compared to GLDAS, WGHM and RESS from Guri dam,

(e) GRACE water storage variations in the Lower Orinoco basin $\left(350000 \mathrm{~km}^{2}\right)$ compared to WGHM

(f) same as e but comparison with NOAH SMS. Water storage variations from the inundated area along the course of the river are not modeled in GLDAS and may explain remaining discrepancy with GRACE.

The contribution of this single reservoir is significant, similar to the soil moisture contribution modeled by NOAH, and explains $25 \%(50 \mathrm{~mm})$ of seasonal variations in the lower Orinoco basin $\left(350000 \mathrm{~km}^{2}\right)$ and shifts the phase by 15 to 20 days (Table S2). This single lake explains nearly entirely the positive trend on the investigated period (20 $\mathrm{mm} / \mathrm{year} ; 7$ $\mathrm{km} 3 / \mathrm{yr}$ ), while $\mathrm{NOAH}$ models a decreasing trend (Table S3). At the scale of the Orinoco basin as a whole $\left(1 \mathrm{M} \mathrm{km}^{2}\right)$, the Guri lake still contributes $\sim 10 \%$ of the seasonal variations in water storage, and $65 \%$ of the trend at the scale of the basin 
Table S3: Comparison between GRACE, $\triangle S M S$ and $\triangle R E S S$ for the Lower Orinoco basin (350 $\left.000 \mathrm{~km}^{2}\right)$

\begin{tabular}{|c|c|c|c|c|c|c|}
\hline & $\begin{array}{c}\text { GRACE } \\
\text { CSR }\end{array}$ & $\begin{array}{c}\triangle \mathrm{RES} \\
\text { Contribution } \\
\text { to GRACE }\end{array}$ & $\mathrm{NOAH}$ & $\begin{array}{l}\text { NOAH + } \\
\triangle \text { RESS }\end{array}$ & WGHM & $\begin{array}{c}\text { WGHM + } \\
\triangle \text { RESS }\end{array}$ \\
\hline Seasonal amplitude [mm] & 199 & $51(25 \%)$ & 85 & 129 & 116 & 143 \\
\hline Phase (seasonal) [ days ] & Ref. & +39 & -14 & 0 & -28 & -8 \\
\hline Correlation & Ref. & & 0.87 & 0.93 & 0.84 & 0.91 \\
\hline Trend [ mm/yr ] & 22 & 20 & -4.6 & 16 & 16 & 36 \\
\hline Trend [ $\mathrm{km}^{3} / \mathrm{yr}$ ] & 7.7 & 7 & -1.6 & 5.6 & 5.6 & 12.6 \\
\hline
\end{tabular}

Table S4: Comparison between GRACE, $\triangle S M S$ and $\triangle R E S$ for Orinoco basin $\left(1 \mathrm{M} \mathrm{km}^{2}\right)$

\begin{tabular}{|c|c|c|c|c|c|c|}
\hline & $\begin{array}{c}\text { GRACE } \\
\text { CSR }\end{array}$ & $\begin{array}{c}\Delta \text { RES } \\
\text { Contribution } \\
\text { to GRACE }\end{array}$ & NOAH & $\begin{array}{c}\text { NOAH + } \\
\Delta \text { RESS }\end{array}$ & WGHM & $\begin{array}{c}\text { WGHM + } \\
\Delta \text { RESS }\end{array}$ \\
\hline Seasonal amplitude [mm] & $\mathbf{1 8 5}$ & $16.5(9 \%)$ & 113 & $\mathbf{1 2 7}$ & 146 & $\mathbf{1 5 6}$ \\
\hline Phase (seasonal) [ days ] & Ref. & +44 & +7 & $\mathbf{+ 1 1}$ & -10 & $-\mathbf{5}$ \\
\hline Correlation & $\mathbf{R e f .}$ & & 0.78 & $\mathbf{0 . 8 3}$ & 0.93 & $\mathbf{0 . 9 5}$ \\
\hline Trend [ $\mathrm{mm} / \mathrm{yr}$ ] & $\mathbf{8 . 1}$ & 5.3 & -23 & $\mathbf{- 1 8}$ & 10 & $\mathbf{1 6}$ \\
\hline Trend [ $\mathrm{km}^{3} / \mathrm{yr}$ ] & $\mathbf{8 . 1}$ & 5.3 & -23 & $\mathbf{- 1 8}$ & 10 & $\mathbf{1 6}$ \\
\hline
\end{tabular}




\section{East African Lakes}

a)

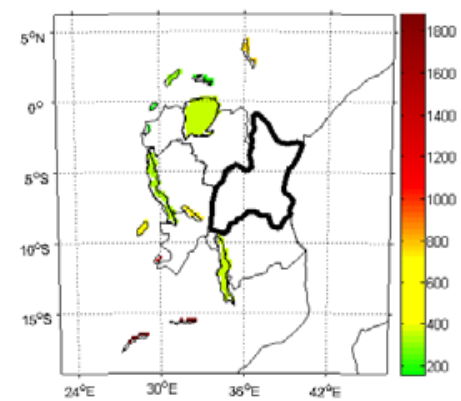

b)

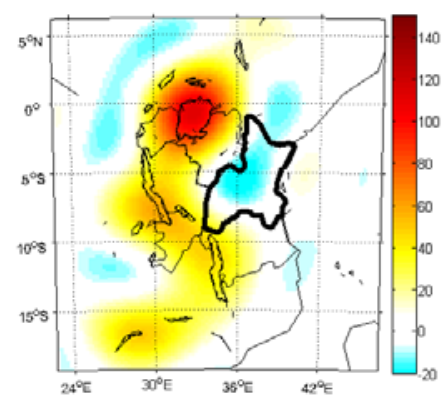

c)

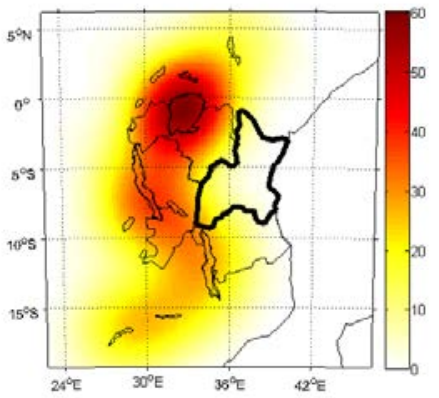

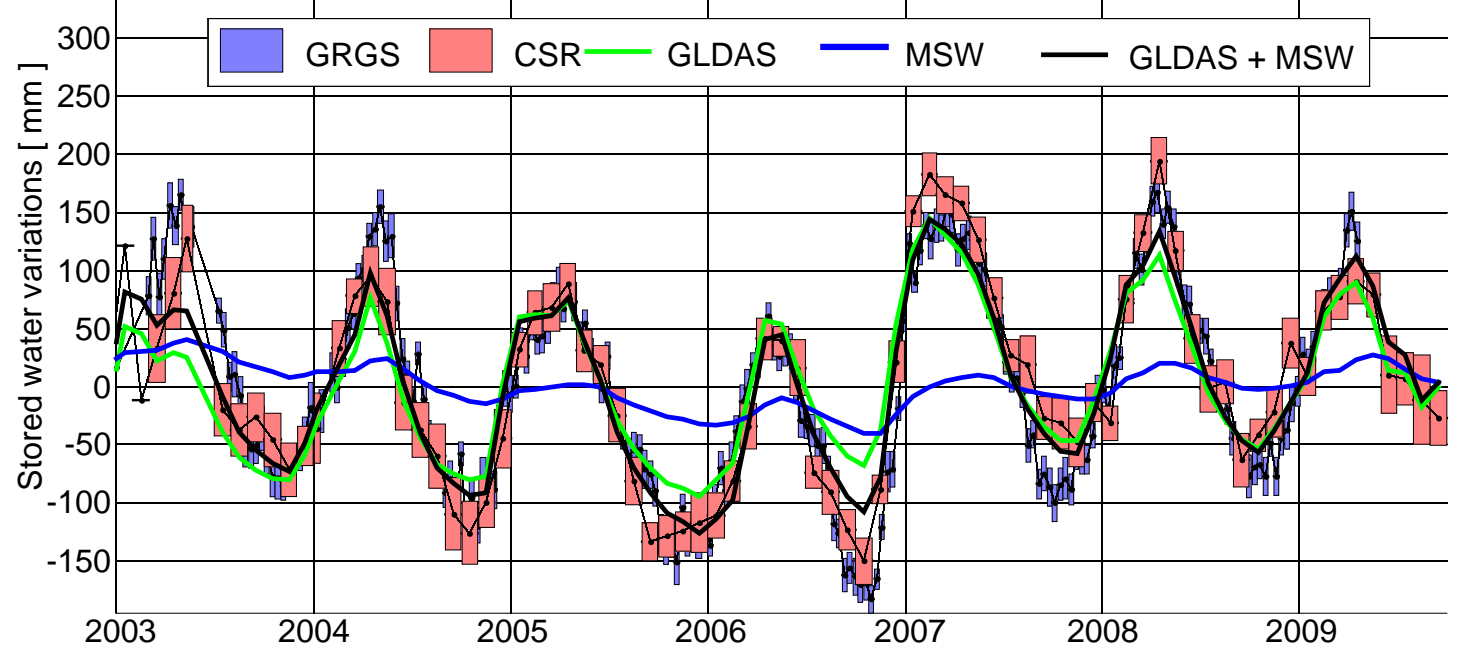

d)

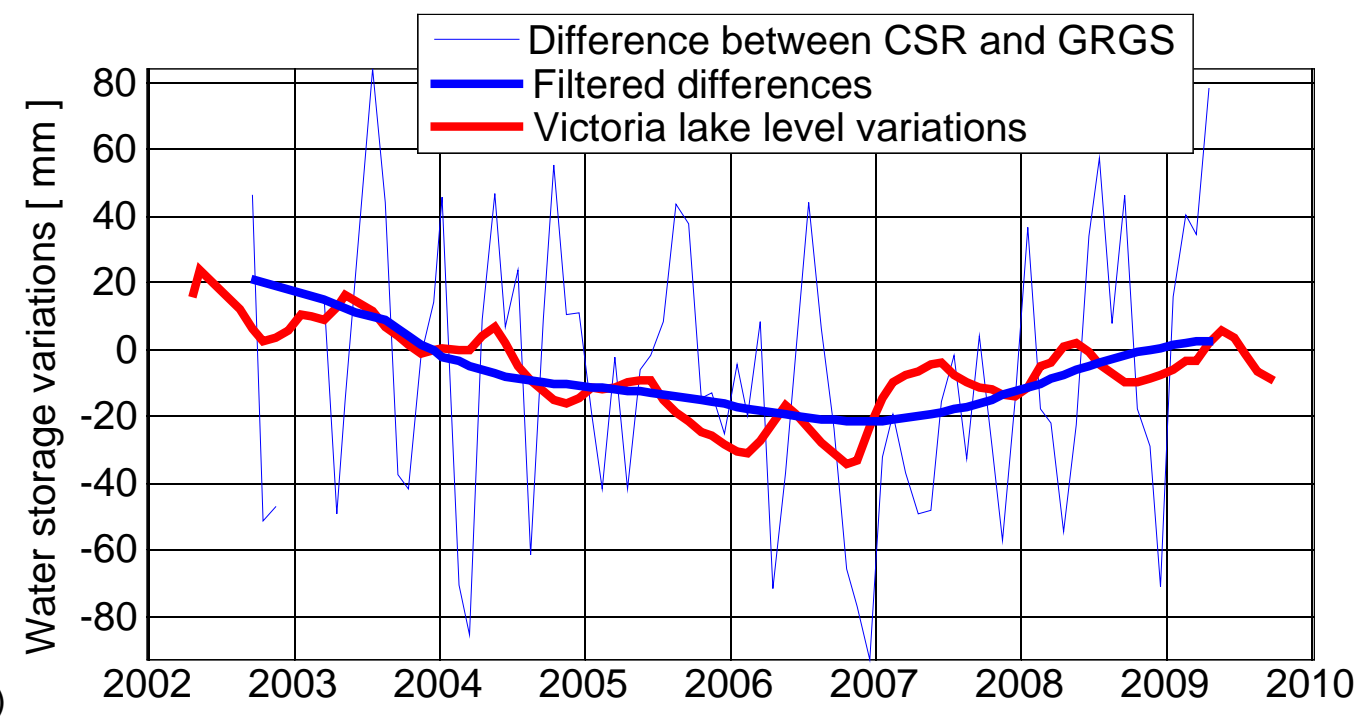

Figure S5: This example illustrate the East African lake contribution to GRACE from Xie et al.,[2012].

(a) Reservoir distribution and mass variations for each of the 34 lakes, the thin outline shows Tanzania (1 $\left.125000 \mathrm{~km}^{2}\right)$, the thick outline shows the North Tanzanian Coastal Basin $\left(355000 \mathrm{~km}^{2}\right)$. Note that most of the lakes are located at the edge or outside Tanzania. No lake is located within the North Tanzanian Coastal Basin

(b) Associated mass variations after truncation to degree 50, similar to GRGS processing,

(c) Mass variations after truncation at degree 60 with 300-km Gaussian smoothing, similar to CSR processing. Note that the predicted lake effect on GRGS and CSR shows different leakage amplitudes and signs in the North Tanzanian Coastal Basin. 
120 (d) Comparison between lake storage, GLDAS NOAH SMS, and GRACE over Tanzania as a whole. While most of the lakes are located at the edge or outside Tanzania, the inter-annual lake contribution is significant and reaches $80 \mathrm{~mm}$ (min-max) over this large basin.

e) Difference between CSR and GRGS solution over the North Tanzanian Coastal Basin. As predicted, the lake effect on CSR and GRGS has different leakage signs in this region, this should show up in the data. RMS difference between CSR and GRGS is $\sim 39 \mathrm{~mm}$. After filtering high-frequency noise, the long-term residuals show a clear correlation with Lake Victoria level variations $(r=0.88)$. While Lake Victoria is more than $300 \mathrm{~km}$ from the outline of the North Tanzanian Coastal basin, leakage from this lake is still important, and explains the differences between the two different GRACE processing strategies (CSR and GRGS). 